\title{
Pelaksanaan Peraturan Kepala Desa No.4 Tahun 2019 Tentang Uang Adat di Desa Koto Mudik
}

\author{
Barqah Nosi Helpia, Henni Muchtar \\ Prodi Pendidikan Pancasila dan Kewarganegaraan \\ FIS Universitas Negeri Padang \\ E-mail: barqahnosihelpia@gmail.com
}

\begin{abstract}
ABSTRAK
Artikel ini bertujuan untuk mengetahui apa saja kendala yang terjadi dalam pelaksanaan peraturan kepala desa no.4 tahun 2019 mengenai ketetapan uang adat di Desa Koto Mudik Kec. Air Hangat Barat Kab. Kerinci. Metode penelitian dilakukan melalui metode deskriptif dengan pendekatan kualitatif. Informan penelitian sebanyak 29 orang yaitu terdiri dari kepala desa, sekretaris desa, pemangku adat, ketua BPD, pelaku pelanggaran dan masyarakat Desa Koto Mudik. Teknik pengumpulan data yang digunakan adalah wawancara, observasi dan studi dokumentasi. Uji keabsahan data menggunakan teknik triangulasi data dan selanjutnya data yang diperoleh akan analisis melalui tahap reduksi data, penyajian data dan penarikan kesimpulan. Hasil penelitian menunjukan bahwa pelaksanaan peraturan kepala desa no.4 tahun 2019 tentang uang adat pada pelaksanaanya masih belum efektif. Terdapat beberapa kendala dalam pelaksanaan peraturan kepala desa no.4 tahun 2019 tentang uang adat di Desa Koto Mudik yaitu masalah perekonomian masyarakat, adanya perlakuan yang tidak adil dari pemangku adat, tidak tegasnya perangkat desa dan pemangku adat dalam penetapan denda uang adat, juga kurangnya pemahaman dan pengetahuan masyarakat mengenai peraturan yang berlaku di Desa Koto Mudik.
\end{abstract}

Kata Kunci: uang adat, Koto Mudik, peraturan kepala desa

\section{ABSTRACT}

This article aims to find out what are the obstacles that occur in the implementation of village head regulation no.4 in 2019 regarding the provision of customary money in the village of Koto Mudik Kec. West Warm Water District. Kerinci. The research method is done through descriptive methods with a qualitative approach. Research informants as many as 29 people consisting of the village head, village secretary, traditional stakeholders, chair of the $B P D$, violators and the community of Koto Mudik Village. The results showed that the implementation of the village head regulation no.4 in 2019 regarding adat money had not been carried out optimally. There are several obstacles in the implementation of the village head regulation no.4 of 2019 regarding customary money, namely the economic problems of the Koto Mudik Village community, the existence of unfair treatment from customary stakeholders, the indecisiveness of village officials and customary stakeholders in the 
determination of adat customary fines, also the lack of understanding and knowledge of the community regarding the regulations in Koto Mudik Village.

Keywords: customary money, Koto Mudik, regulation of the village head

(c) (7) (2) This work is licensed under the Creative Commons Attribution-ShareAlike 4.0 International License. EY 24 author.

\section{PENDAHULUAN}

Desa merupakan hal yang menarik untuk dijadikan sebagai bahan kajian karena memiliki karakter atau ciri tersendiri baik dari segi sosial, budaya, politik maupun ekonomi. Desa yang biasa disebut dengan negeri, kampong, dusun, dati dan sebagainya merupakan sebuah kelompok adat yang memiliki bentuk pemerintahan paling rendah dalam struktur tata urutan pemerintahan di Indonesia.

$$
\text { Sesuai dengan Undang- }
$$
Undang No.6 tahun 2014 yang menyebutkan bahwa desa memiliki wewenang untuk memberikan kesempatan kepada daerah dalam membentuk pemerintahan desa berdasarkan adat istiadat menurut hak asal usul dari kesatuan masyarakat hukum adat setempat. Selain kewenangan yang berasal dari hak asal usul, pemerintahan desa juga memperoleh kewenangan dari pemerintah Kabupaten/Kota melalui pelimpahan yang bersifat delegatif. Bentuk-bentuk kewenangan yang dapat didelegasikan kepada desa sendiri meliputi penyelenggaraan pemerintahan desa, pelaksanaan pembangunan desa, pembinaan kemasyarakatan desa dan pemberdayaan masyarakat desa.

Peraturan tersebut sebagai landasan dan payung hukum dan juga acuan bagi pemerintahan Daerah Kabupaten/Kota dalam membentuk sistem pemerintahan desa dalam rangka menjalankan kepentingan masyarakat pemerintahan desa perlu untuk menyusun peraturan desa, sepanjang mengenai teknis pelaksanaanya yang diatur lebih lanjut oleh peraturan kepala desa dan berlaku sejak tanggal diundangkan.

Sehingga dengan demikian diketahui bahwa peraturan desa merupakan peraturan perundangundangan yang ditetapkan oleh kepala desa setelah dibahas dan disepakati bersama Badan Permusyawaratan Desa (BPD). Selanjutnya peraturan kepala desa merupakan peraturan yang ditetapkan oleh kepala desa dan bersifat mengatur. Sedangkan keputusan kepala desa adalah keputusan yang ditetapkan oleh kepala desa yang bersifat menetapkan dalam rangka melaksanakan peraturan desa maupun peraturan kepala desa.

Untuk menjalankan kewenangan desa yang berdasarkan pembinaan masyarakat setiap desa memiliki peraturan desa dengan ciri khas masing-masing. Pada Desa Koto Mudik Kec. Air Hangat Barat Kab. Kerinci pemerintah Desa Koto Mudik membuat peraturan kepala desa dengan tujuan agar setiap masyarakat dapat mengetahuinya dan 
Journal of Civic Education (ISSN: 2622-237X) Volume 3 No. 32020

pengundangan peraturan kepala desa ini dengan menempatanya dalam lambaran desa.

Mengenai hal tersebut peraturan kepala desa yang dibuat oleh pemerintah Desa Koto Mudik berdasarkan atas landasan sosiologis empiris, yang dibuat dalam keadaan mendesak dan bersifat sementara yang memiliki batas waktu tertentu (masa tenggang). Terdapat beberapa pertimbangan sosiologis empiris dalam penyusunan Peraturan Kepala Desa No.4 Tahun 2019 tentang uang adat yaitu, karena rendahnya pemahaman dan kepatuhan masyarakat terhadap peraturan yang berlaku. Hal ini dapat dilihat dari kehidupan masyarakat Desa Koto Mudik yang belum terbimbing dengan baik, perilaku masyarakat yang semakin banyak tidak mengikuti aturan yang ada. Pemerintah Desa Koto Mudik berharap dengan adanya peraturan kepala desa tentang uang adat masyarakat bisa mengendalikan diri dalam melakukan perbuatan dan perilaku dalam kehidupan bermasyarakat.

Selanjutnya masyarakat harus membayar uang adat pernikahan Rp. 1.000.000, uang adat pernikahan diluar desa Rp.1.500.000, uang adat perceraian Rp.700.000, uang njuk tau Rp. 100.000, uang adat tukun lantak Rp. 350.000, uang adat tambah induk Rp. 25.000/orang. Begitupun dengan apabila masyarakat Desa Koto Mudik melakukan pelanggaran maka harus membayar sesuai dengan jenis pelanggaran yang dilakukan, yaitu nikah sumbang Rp.250.000, nikah siri Rp.500.000, hamil diluar nikah Rp.1000.000, janda hamil dengan suami yang tidak sah/suami orang
Rp.1.500.000, melarikan anak gadis/melarikan istri orang Rp.2.500.000, dan melanggar peraturan desa Rp.1000.000.

Namun dalam hal ini masih banyak masyarakat Desa Koto Mudik yang tidak patuh terhadap peraturan tersebut dimana masih terlihat masyarakat yang tidak membayar uang adat sesuai dengan ketetapan yang berlaku dan masih ada masyarakat yang melakukan perbuatan pelanggaran seperti nikah sumbang, nikah siri, hamil diluar nikah, melarikan anak gadis orang dengan pembayaran denda uang adat dibayar tidak sesuai dengan ketentuan yang terdapat dalam peraturan kepala desa tersebut.

Penelitian tentang pelaksanaan denda adat telah banyak dilakukan oleh peneliti-peneliti terdahulu, antara lain: penelitian yang berjudul Penerapan Sanksi Adat dalam Penyelesaian Perkara Pidana di Kabupaten Nagari Raya, dilakukan oleh Safrijal Airil (2013). Penelitian ini memfokuskan terhadap masalah penyelesaian adat yang dilakukan dengan asas perdamaian. Kemuadian penelitian yang berjudul Denda Adat dalam Penjatuhan Pidana di Pengadilan Negeri Marauke Papua, oleh Elmina (2014). Penelitian ini memfokuskan penyelesaian masalah pada orang yang melakukan kejahatan diharuskan membayar denda adat berupa denda darah yang dapat juga diwujudkan dalam bentuk bantuan biaya pengobatan dan pembayaran denda.

Penelitian lain juga membahas tentang denda adat yang berjudul Peran Hukum Adat dalam Penyelesaian Kasus Kekerasan 
Terhadap Perempuan di Kupang, oleh Nafi dkk (2016). Penelitian ini fokus kepada penyelesaian denda adat atas kasus kekerasan kepada perempuan. Selanjutnya penelitian yang berjudul Sanksi Adat Bagi Pelaku Kekerasan Fisik Ditinjau Menurut Hukum Pidana Islam.

Hal inilah yang membedakan penelitian ini dengan penelitian sebelumnya, penelitian ini membahas yang terkait dengan pelaksanaan Peraturan Kepala Desa No.4 Tahun 2019 tentang uang adat dan kendala yang dihadapi dalam pelaksanaan peraturan tersebut di Desa Koto Mudik Kec Air Hangat Kab. Kerinci.

\section{METODE PENELITIAN}

Penelitian ini merupakan penelitian kualitatif dengan menggunakan metode deskriptif, karena penelitian ini berusaha untuk mendiskripsikan gambaran yang terjadi pada lokasi penelitian. Lokasi penelitian dilakukan di Desa Koto Mudik Kec.Air Hangat Barat Kab. Kerinci karena lokasi ini memiliki peraturan kepala desa dan disana terdapat masyarakat yang melakukan pelanggaran dan tidak patuhnya masyarakat terhadap peraturan. Untuk mempermudah peneliti mendapatkan informan dan informasi yang relevan, disini peneliti memilih purposif sampling. Dalam penelitian ini informan berjumlah 29 orang. Penentuan informan yaitu dari responden atau orang yang benar memahami persoalan yang terjadi untuk memberikan informasi seperti Kepala Desa, Sekretaris Desa, Ketua BPD, Pemangku Adat, pelaku pelanggaran dan masyarakat di Desa Koto Mudik Kec. Air Hangat Barat Kab. Kerinci. Teknik pengumpulan data dengan menggunakan teknik wawancara, observasi dan studi dokumentasi. Sumber data dalam penelitian ini menggunakan data primer dimana data didapatkan dari hasil observasi dan wawancara di lapangan. Selanjutnya data sekunder dapat diperoleh dari hasil studi dokumentasi di lokasi penelitian. Untuk menguju keabsahan data dalam penelitian, penulis menggunakan teknik triangulasi sumber. Selanjutnya data yang diperoleh akan analisis melalui tahap reduksi data, penyajian data dan penarikan kesimpulan.

\section{HASIL DAN PEMBAHASAN}

Berdasarkan hasil penelitian yang ditemukan dilapangan dalam pelaksanaan Peraturan Kepala Desa No.4 Tahun 2019 tentang uang adat belum terlaksana secara efektif, seharusnya pelaksanaan peraturan ini mampu memenuhi kebutuhan masyarakat, membimbing masyarakat dan mengatur kehidupan bermasyarakat Desa Koto Mudik. Namun pada pelaksanaanya tidak semua pelaksanaan peraturan berjalan dengan sebagaimana yang tertera.

Berdasarkan teori Van Meter dan Van Hord dalam Indiahono (2009:38), menunjukan variabel yang berperan penting dalam pencapaian keberhasilan pelaksanaan, sebagai berikut:

a) Standar dan sasaran kebijakan

Untuk menentukan persyaratan persetujuan dan tujuan suatu peraturan yang harus disetujui oleh para pelaksana peraturan, mereka menetapkan kebijakan tentang anggaran yang sesuai dengan tingkat keberhasilan. Arah disposisi para pelaksana terhadap standar dan tujuan 
Journal of Civic Education (ISSN: 2622-237X)

Volume 3 No. 32020

kebijakan merupakan hal yang sangat penting. Pelaksanaan bisa jadi gagal dalam melaksanakan kebijakan, karena mereka bisa menolak atau tidak mengerti apa yang menjadi tujuan kebijakan.

Dari hasil pengamatan dan wawancara yang peneliti dapatkan di lapangan bahwa Peraturan Kepala Desa No.4 Tahun 2019 Tentang Uang Adat di Desa Koto Mudik dibuat oleh perangkat desa bersama dengan pemangku adat karena dalam keadaan yang mendesak dan terpaksa untuk membuat peraturan tersebut sehingga di buat peraturan kepala desa sesuai dengan kebutuhan masyarakat setempat supaya dapat membimbing masyarakat dalam melakukan suatu perbuatan. Kemudian uang adat mengenai denda pelanggaran yang harus dibayar oleh si pelanggar sebagai suatu upaya agar adanya efek jera bagi sipelaku pelanggaran yang melakukan perbuatan menyimpang sehingga tidak melakukan perbuatan itu lagi.

b) Sumber daya

Keberhasilan pelaksanaan kebijakan sangat tergantung pada kemampuan pemanfaatan sumberdaya yang tersedia. Manusia merupakan sumber daya yang terpenting dalam menentukan keberhasilan suatu pelaksanaan kebijakan. Setiap perangkat menerapkan persyaratan sumber daya manusia yang sesuai dengan pekerjaan yang diperlukan oleh kebijakan yang telah menentukan oleh apolitik.

Pada penelitian yang telah peneliti lakukan pada saat pengamatan dan wawancara di lapangan menunjukan bahwa sumber daya manusia disini adalah perangkat desa yang terdiri dari kepala desa, sekretaris desa, anggota BPD dan hansip desa. Kemudian pemangku adat yang terdiri dari ketua adat dan anggotanyayang telah memiliki fungsi dan tugasnya masing-masing agar peraturan berjalan sesuai dengan tujuan yang diharapkan.

c) Karakteristik organisasi pelaksana

Organisasi formal dan informal yang akan terlibat dalam kebijakan pelaksanaan menjadi pusat perhatian pada agen pelaksana. Pentingnya hal tersebut karena pelaksanaan kebijakan akan sangat diperlukan oleh para agen pelaksananya. Hal ini sangat berkaitan dengan kebijakan yang akan dilakukan pada kebijakan yang dituntut pelaksana kebijakan ketat dan disiplin. Pada hal lain diperlukan pelaksana yang dirancang dan persuasif. Selain itu, persetujuan atau wilayah luas menjadi pertimbangan penting dalam menentukan agen pelaksana kegiatan.

Pada peraturan tentang uang adat, perangkat desa dan pemangku adat memiliki beberapa cara atau strategi dalam penetapan uang adat yaitu dengan bekerja sama antara perangkat desa, pemangku adat dan masyarakat Desa Koto Mudik yang memiliki sifat kemitraan konsultatif dan koordinatif, sehingga peraturan tersebut dapat terlaksana dengan sebaik mungkin. Pada kenyataanya cara atau strategi yang dipakai oleh perangkat desa dalam melaksanakan peraturan uang adat tidak sejalan dengan apa yang seharusnya, dimana masyarakat tidak percaya lagi karena adanya perlakuan yang tidak adil yang saling melindungi keluarga masingmasing dari pemangku adat. 
d) Komunikasi antar organisasi terkait kegiatan pelaksana

Agar kebijakan publik dapat dilaksanakan dengan efektif, apa yang menjadi standar harus ditentukan oleh individu (pelaksana), yang bertanggung jawab atas persetujuan standar dan tujuan. Karena standar dan tujuan harus dikomunikasikan kepada para pelaksana. Komunikasi dalam resolusi penyampaian informasi kepada para pelaksana kebijakan tentang apa yang menjadi standar dan tujuan harus diverifikasi dan seragam (konsistensi dan keseragaman) dari berbagai sumber informasi. Dalam suatu organisasi publik seperti pemerintah daerah, komunikasi sering merupakan proses yang sulit dan kompleks.

Agar peraturan kepala desa dapat dilaksanakan dengan efektif harus adanya komunikasi dengan baik antara perangkat desa, pemangku adat dan masyarakat Desa Koto Mudik, dimana masyarakat harus terlibat dalam proses pelaksanaan peraturan. Namun pada pelaksanaanya belum ada sosialisasi mengenai peraturan kepala desa tentang uang adat yang menyebabkan masyarakat tidak mengetahui berapa yang seharusnya dibayar pada penetapan uang adat tersebut.

e) Disposisi atau sikap para pelaksana

Peraturan kepala desa tentang uang adat terlihat bahwa adanya sikap tidak adil dari perangkat desa dalam penetapan denda uang adat yang mana mereka saling melindungi keluarga masing-masing. Akibatnya masyarakat tidak percaya lagi dengan perangkat desa dan pemangku adat sehingga masyarakat tidak membayar denda uang adat sesuai dengan ketetapan yang sudah berlaku, menyebabkan pelaksanaannya tidak berjalan dengan baik.

f) Lingkungan sosial ekonomi dan politik

Hal terakhir yang menjadi pertimbangan untuk meningkatkan kebijakan implementasi adalah kebijakan mana yang mendukung kebijakan publik. Lingkungan sosial, ekonomi, dan politik yang tidak kondusif dapat menjadi sumber masalah. Karena itu, penerapan kebijakan mensyaratkan persyaratan lingkungan eksternal yang kondusif.

Pada lingkungan Desa Koto Mudik peraturan kepala desa tentang uang adat peraturan tersebut cocok diterapkan karena sesuai dengan kebutuhan masyarakat yang telah disesuaikan dengan perekonomian desa. Tetapi pada pelaksanaannya penerimaan masyarakat terhadap peraturan kepala desa tidak berjalan sesuai dengan peraturan yang berlaku. Hal tersebut disebabkan oleh ketidaktegasan perangkat desa dan pemangku adat dalam melaksanakan peraturan, adanya sikap diskriminasi dari pemangku adat yang menyebabkan masyarakat tidak percaya lagi dengan perangkat desa dan pemangku adat. Sehingga dengan menjadikan masalah perekonomian sebagai salah satu alasan kendala untuk masyarakat tidak membayar denda uang adat.

Jadi dapat dipahami bahwa pelaksanaan peraturan Kepala Desa No.4 Tahun 2019 tentang uang adat di Desa Koto Mudik Kerinci belum terlaksana secara optimal, dapat dilihat dari masih ada masyarakat yang melakukan pelanggaran dan tidak patuh terhadap peraturan yang 
Journal of Civic Education (ISSN: 2622-237X)

Volume 3 No. 32020

sudah berlaku. Peraturan kepala desa hanyalah sebuah aturan yang telah di SKkan oleh kepala desa tetapi tidak dijalankan dengan semestinya. Peraturan tersebut hanya formalitas saja tetapi yang paling berhak menentukan dan memutuskan denda uang adat diberikan terhadap orang yang melakukan pelanggaran terhadap peraturan tergantung ketetapan dari pemangku adat dan perangkat desa Koto Mudik. Ini dapat dilihat lebih jelasnya sebagai berikut:

Tabel 1

Bentuk Pelanggaran Peraturan Kepala Desa No.4 tahun 2019 tentan

\begin{tabular}{|l|l|l|l|l|}
\hline \multicolumn{1}{|c|}{ No } & $\begin{array}{l}\text { Bentuk } \\
\text { Pelanggaran }\end{array}$ & $\begin{array}{c}\text { Jumlah } \\
\text { pelanggaran }\end{array}$ & Penyelesaian & $\begin{array}{l}\text { Penyelesaian } \\
\text { seharusnya }\end{array}$ \\
\hline 1. & $\begin{array}{l}\text { Nikah } \\
\text { Sumbang }\end{array}$ & 5 orang & $\begin{array}{l}\text { Dibayar } \\
\text { dengan 1 sisir } \\
\text { pisang }\end{array}$ & $\begin{array}{l}\text { Rp.250.000,- } \\
\text { atau 1 kayu } \\
\text { kain }\end{array}$ \\
\hline 2. & Nikah siri & 2 orang & $\begin{array}{l}\text { Dibayar } \\
\text { Rp.100.000,-- }\end{array}$ & $\begin{array}{l}\text { Rp.500.000,-- } \\
\text { atau 2 kayu } \\
\text { kain }\end{array}$ \\
\hline 3. & $\begin{array}{l}\text { Hamil diluar } \\
\text { nikah }\end{array}$ & 1 orang & $\begin{array}{l}\text { Tidak } \\
\text { dibayar }\end{array}$ & $\begin{array}{l}\text { Rp.1.500.000,-- } \\
\text { atau 6 kayu } \\
\text { kain }\end{array}$ \\
\hline 4. & $\begin{array}{l}\text { Janda hamil } \\
\text { dengan } \\
\text { suami yang } \\
\text { tidak } \\
\text { sah/suami } \\
\text { orang }\end{array}$ & - & - & $\begin{array}{l}\text { Rp.1.500.000,- } \\
\text { atau 6 kayu } \\
\text { kain }\end{array}$ \\
\hline 5. & $\begin{array}{l}\text { Melarikan } \\
\text { anak anak } \\
\text { gadis/kabur }\end{array}$ & 3 orang & $\begin{array}{l}\text { Tidak } \\
\text { dibayar }\end{array}$ & $\begin{array}{l}\text { Rp.2.500.000,-- } \\
\text { atau 10 kayu } \\
\text { kain }\end{array}$ \\
\hline 6. & $\begin{array}{l}\text { Melanggar } \\
\text { peraturan } \\
\text { desa }\end{array}$ & 18 orang & Rp.150.000,-- & $\begin{array}{l}\text { Rp.1000.000,-- } \\
\text { atau 4 kayu } \\
\text { kain }\end{array}$ \\
\hline
\end{tabular}

Sumber: penelitian di Desa Koto Mudik

Dari tabel di atas dapat dilihat bahwa terdapat beberapa peraturan uang adat yang tidak dijalankan oleh masyarakat Desa Koto Mudik. Peneliti mendapatkan enam bentuk pelanggaran yang dikenakan denda kepada setiap pelanggarnya. Dari enam bentuk pelanggaran, hanya satu jenis pelanggaran yang tidak dilakukan masyarakat setempat yakni hubungan seorang janda dengan seorang pria beristri. Kasus-kasus pelanggaran ini menjadi perhatian bagi pemerintahan desa dan lembaga adat dalam pelaksanaan Peraturan ini.

Selanjutnya dalam pelaksanaan peraturan kepala desa no.4 tahun 2019 tentang uang adat di Desa Koto Mudik terdapat beberapa kendala. Oktaviani
(2013:16-18), mengatakan bahwa terdapat beberapa kendala dalam pelaksanaan peraturan antara lain yaitu pengetahuan hukum, proses perencanaan membuat peraturan, pada saat membuat materi muatan perundang-undangan yang dilakukan melalui musyawarah yang berupaya untuk menyatukan pemikiranpemikiran. Kemudian kurangnya kemauan untuk membuat produk hukum baru, pro dan kontra yang berkepanjangan, ada yang setuju dan tidak setuju dalam pelaksanaan peraturan itu yang membuat pelaksanaan peraturan menjadi lama, hubungan peraturan perundangundangan dan penafsiran bahasa hukum, membuat pemerintahan kesulitan dalam menafsirkan bahasa peraturan perundang-undangan yang terkadang memiliki banyak arti dan bahasa yang sulit untuk dimengerti.

Kendala dalam pelaksanaan peraturan kepala desa ini adalah tingkat ekonomi yang tidak sama sehingga menyebabkan masyarakat kesusahan dalam pembayaran uang adat. Kemudian perlakuan yang tidak adil dari pemangku adat dalam penetapan denda uang adat. Kendala selanjutnya adalah tidak tegasnya perangkat desa dan pemangku adat dalam penetapan denda uang adat. Kendala terakhir adalah kurangnya pemahaman dan pengetahuan dari masyarakat. Kurangnya sosialisasi dari perangkat desa mengenai peraturan kepala desa tentang uang adat ini.

\section{KESIMPULAN}

Pelaksanaan peraturan kepala desa no.4 tahun 2019 tentang uang adat masih belum efektif, Masih terdapat beberapa permasalahan 
dalam pelaksanaan seperti kurang tegas perangkat desa dan pemangku adat dalam penetapan denda uang adat dan masih ada masyarakat yang tidak membayar denda uang adat sesuai dengan jumlah uang dalam peraturan kepala desa. Hal ini mengakibatkan peraturan kepala desa no.4 tahun 2019 tentang uang adat di Desa Koto Mudik tidak berjalan dengan baik, yang disebabkan oleh beberapa kendala yaitu pertama, perekonomian masyarakat Desa Koto Mudik. Kedua, adanya perlakuan yang yang tidak adil dari perangkat desa dan pemangku adat dalam penetapan denda uang adat. Ketiga, tidak tegasnya perangkat desa dan pemangku adat dalam penetapan denda uang adat. Keempat, kurangnya pensosialisasian mengenai peraturan yang berlaku sehingga masyarakat kurang pemahaman dan pengetahuan mengenai Peraturan Kepala Desa no.4 tahun 2019 tentang uang adat.

\section{DAFTAR PUSTAKA}

Akmal, A., \& Muchtar, H. (2018). Bureaucracy from the Human Rights Perspective and Its Effect on Public Service. Journal of Moral and Civic Education, 2(2), 52-63.

Asshiddiqie, Jimly. 2011. Konstitusi dan Konstitusinalisme Indonesia. Jakarta: Sinar Grafika

Elmina, 2014. Penyelesaian denda adat pada persfektif hukum islam. Jurnal Hukum Adat. Vo.2. Hal. $1-5$

Indiahono, 2009. Implementasi kebijakan publik. Jakarta: Bumi Aksara

Muchtar, Henni. 2015. Pengembangan Ilmu Hukum di Indonesia. Jurnal Demokrasi. Vol, IX No. 1.
Nafi dkk, 2016. Kasus Kekerasan Pada Perempuan. Jurnal Hukum Pidana Islam. Vol.4

Novalia, dkk, 2017. Pewarisan Kebudayaan dalam "ICO PAKAI" Hukum Adat Masyarakat Tanjung Pauh Mudik Kec. Keliling Danau Kab. Kerinci. Jurnal Al-qisthu. Vol.15, No.1, Hal 10-15.

Oktaviani, 2013. Pelaksanaan Pembentukan Pwrataturan Desa yang Berkualitas Pasca Pengesahan UU No. 12 Tahun 2011 tentang Pembentukan Peraturan Perundangundangan. Skripsi. Hal.16-18.

Sjarif Amieroedin, 2009. Perundangundangan Dasar, Jenis dan Teknik Membuatnya. Jakarta Rineka Cipta.

Sjafrizal Airil, 2013. Penyelesaian kasus hukum adat di Aceh. Jurnal Hukum Adat. V01.2. Hal. 10-15

Undang-Undang Republik Indonesia No. 6 Tahun 2014 tentang Desa.

Peraturan Kepala Desa Koto Mudik No. 04 Tahun 2019 tentang Ketentuan Uang adat Desa Koto Mudik Kec. Air Hangat Barat Kab. Kerinci. 